\title{
POTENTIAL OF LIVESTOCK MANURE FOR COAL ACTIVATION
}

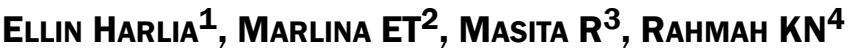 \\ 1,2 Faculty of Animal Husbandry, Padjadjaran University \\ 3, 4 Alumni of Faculty of Animal Husbandry, Padjadjaran University \\ Jln.Raya Bandung-Sumedang Km 21 Jatinangor \\ Email: ellin.harlia@unpad.ac.id
}

Naskah diterima 13 Juli 2016, Naskah disetujui 14 Juni 2017

\begin{abstract}
The natural methane formed by bacteria in anaerobic conditions is known as biogenic gas. Gas trapped in coal, formed through thermogenesis as well as biogenesisis known as coal-bed methane (CBM). The availability of organic material as decomposition of this material into methane is continuously required for the production of methane in the coal aquifer. The aim of this research was to investigate whether or not cattle feces bacteria were able to grow and produce methane in coal. Parameters measured were Volatile Fatty Acids (VFA) and the production of biogas, such as nitrogen, hydrogen, carbon dioxide, and methane. Explorative method was used and data obtained was analyzed by descriptive approach. The results showed that the bacteria found in the feces survived in the coal and produce biogas. On day 2 when the process was at the acidogenesis phase, it produced VFA with the largest component of acetic acid. Acetic acid would undergo decarboxylation and reduction of $\mathrm{CO}_{2}$, followed by reactions of $\mathrm{H}_{2}$ and $\mathrm{CO}_{2}$ to produce methane $\left(\mathrm{CH}_{4}\right)$ and carbon dioxide $\left(\mathrm{CO}_{2}\right)$ as the final products.
\end{abstract}

Key words: Methane, CBM, bacteria, livestock feces

\section{INTISARI}

Metana yang secara alami terbentuk oleh bakteri dalam kondisi anaerobik dikenal dengan nama gas biogenik. Gas yang terperangkap dalam batubara, terbentuk melalui thermogenesis serta biogenesis dikenal dengan gas metana batubara (GMB). Ketersediaan bahan organik sebagai bahan dekomposisi metana diperlukan secara terus menerus untuk produksi metana di akuifer batubara. Tujuan dari penelitian ini adalah untuk mengetahui apakah bakteri feses ternak dapat tumbuh dan menghasilkan metana dalam batubara. Parameter yang diukur adalah Volatile Fatty Acids (VFA) dan produksi biogas, diantaranya nitrogen, hidrogen, karbon dioksida, dan metana. Metode eksploratif digunakan dan data yang diperoleh dianalisis dengan pendekatan deskriptif. Hasilnya menunjukkan bahwa bakteri yang ditemukan di feses ternak dapat bertahan di batubara dan menghasilkan biogas. Pada hari ke 2 pada fase acidogenesis, VFA yang dihasilkan memiliki komponen asam asetat terbesar. Asam asetat akan mengalami dekarboksilasi dan reduksi $\mathrm{CO}_{2}$, diikuti oleh reaksi $\mathrm{H}_{2}$ dan $\mathrm{CO}_{2}$ untuk kemudian menghasilkan metana $\left(\mathrm{CH}_{4}\right)$ dan karbon dioksida $\left(\mathrm{CO}_{2}\right)$ sebagai produk akhir.

Kata kunci: Metana, CBM, bakteri, kotoran ternak

\section{INTRODUCTION}

Biogas in general consists of methane $\left(\mathrm{CH}_{4}\right)$, carbon dioxide $\left(\mathrm{CO}_{2}\right)$, hydrogen $\left(\mathrm{H}_{2}\right)$ and small amounts of other gases. Methane $\left(\mathrm{CH}_{4}\right)$ is a gas that can be used as an alternative and environmental friendly energy source. Recently, non-conventional energy sources, such as coal-bed methane have been widely utilized. In Indonesia, several types of coal, namely Anthracite, Bituminous, Subbitumminous, and Lignite have been utilized as sources of energy (Tim Kajian Batubara Nasional, 2006). Lignite found in the largest number has low heating characteristic. In order to sustain its utilization, this material need to be further processed by using methane-forming microbes (methanogens) derived from cattle feces ina digester scale. Methanogens, especially methanogens fermenting cattle's manure, obtain their nutrition from manure which contains macronutrients,such as carbon, hydrogen, nitrogen, oxygen, phosphate and sulphate needed in large quantities by these microbes. Manure also contains micronutrients, such as $\mathrm{Fe}, \mathrm{Zn}, \mathrm{Bo}, \mathrm{Mn}, \mathrm{Cu}$ and Mo which are needed by the body in small amounts. In the engineering process, the methanogen obtain their nutrients from artificial media in accordance with the need to grow and gas production. Cattle feces still contain microorganisms which can be reduced over anaerobic degradationor biogas process to prevent environmental pollution. It is an alternative source of organic material that can be utilized to maintain the continuity of coalbed methane production. Coal-bed methane (CBM) is a natural gas (hydrocarbons) with methane as the main element, occurs naturally in coal forming process. Coal 
Tabel 1. Average Volatil Fatty Acid

\begin{tabular}{|c|c|c|c|c|c|c|}
\hline Sample & $\mathrm{C}_{2}$ & $\mathrm{C}_{3}$ & ${ }_{\mathrm{i}} \mathrm{C}_{4}$ & ${ }_{n} C_{4}$ & ${ }_{\mathrm{i}} \mathrm{C}_{5}$ & ${ }_{n} C_{5}$ \\
\hline Bbkf-1 & $21.29 \pm 10.24$ & $6.72 \pm 3.87$ & $1.37 \pm 0.82$ & $4.51 \pm 2.76$ & $2.20 \pm 1.35$ & $0.78 \pm 0.26$ \\
\hline Bbkf-2 & $17.14 \pm 9.35$ & $3.52 \pm 1.82$ & $1.97 \pm 1.28$ & $5.61 \pm 3.46$ & $1.98 \pm 1.16$ & $0.76 \pm 0.43$ \\
\hline Bbkf-3 & $22.18 \pm 11.97$ & $2.62 \pm 1.09$ & $1.67 \pm 0.97$ & $4.81 \pm 3.12$ & $1.86 \pm 0.82$ & $0.65 \pm 0.32$ \\
\hline
\end{tabular}

Note : Bbkf-1, BBkf-2, and Bbkf-3: coarse coal + mixture of cattle feces and water (triplication) obtained from Hungate tube.

has pores through which the gas flows. Coal fractures formed as a result of dehydration and tectonic pressure will accompany the coal maturation process (Saghafi, 2001; Karimi, 2005). The purpose of this research was to investigate whether or not the cattle feces bacteria were able to grow and produce methane in coal.

\section{MATERIALS AND METHOD}

This preliminary study was conducted in order to acquire bacterial consortia with the ability to activate coal and produce methane from livestock wastes, such ascattle feces. Cattle feceswere utilized as bacteria sources, while coal was utilized as microbial culture media. Coal used for activation was a mixture of subbituminous and bituminous in two forms, namely fine and coarse coal. Exploratory study with descriptive approach was used in the study, with treatments of: fine coal+ water (Bbh); fine coal + mixture of cattle fecesand water (Bbhf); coarse coal + mixture of cattle fecesand water (Bbkf); and coarse coal + water (Bbk). These treatments were placed in 3 different digesters, namely $30 \mathrm{ml}$ Hungate tube, $600 \mathrm{ml}$ bottles, and 30 liter drums with triplicates. Each treatment is using ratio of 1:1 based on its digester optimal capacity, for example in drums: $10 \mathrm{~kg}$ coal in $10 \mathrm{~kg}$ of water and cattle feces mixture. The parameters measured were biogas production including nitrogen, hydrogen, carbon dioxide, and methane. Observations on the formation of volatile fatty acids (VFA) using GC were also conducted from Hungate tube on the day 2 with triplicates.

\section{RESULTS}

The biogas formation process in digesters occurred in three stages, namely Hydrolysis, Acidogenesis, and Methanogenesis. In the hydrolysis stage, complex molecules are degraded into simpler molecules. This will be followed by acid production by bacteria which modify short compound produced in the hydrolysis phase into simple organic acids such as acetic acid, $\mathrm{H}_{2}$ and $\mathrm{CO}_{2}$.

Table 1 show the average acetic acid production which is higher than other volatile fatty acids, suggesting that the potential for methane formation is very high or about $70 \%$ of methane is formed from acetic acid, while the remaining is formed from hydrogen and carbon dioxide. The average \% mol of hydrogen produced in the digesters is shown in Table 2.
Tabel 2. Average $\mathrm{H}_{2}$ Production in Several Digesters (\% Mol)

\begin{tabular}{lrrc}
\hline $\begin{array}{l}\text { Treat- } \\
\text { ment }\end{array}$ & $\begin{array}{c}\text { Hungate } \\
\text { Tubes }\end{array}$ & Digester 600 ml & Digester 30 litre \\
& --- & - & \\
Bbhf & - & $0.0276 \pm 0.0165$ & - \\
Bbkf & - & $0.5911 \pm 0.0135$ & $2.33 \pm 0.28$ \\
Bbk & - & - & $1.23 \pm 0.15$ \\
Bbh & - & $0.7076 \pm 0.9256$ & - \\
\hline Note: & & \\
Bbhf = fine coal + mixture of cattle feces and water \\
Bbkf = coarse coal + mixture of cattle feces and water \\
Bbk = coarse coal + water \\
Bbh = fine coal+ water
\end{tabular}

The digesters were also found to produce $\mathrm{CO}_{2}$ and $\mathrm{N}_{2}$ and the average amounts of theses gas produced in each digester are presented in Table 3 and 4, respectively.

Tabel 3. Average $\mathrm{CO}_{2}$ Production in Different Digester (\% Mol)

\begin{tabular}{|c|c|c|c|}
\hline \multirow{2}{*}{ Treatment } & Hungate Tubes & Digester $600 \mathrm{ml}$ & Digester 30 litre \\
\hline & \multicolumn{3}{|c|}{------------------- \%Mol--------------------- } \\
\hline$\overline{B b h f}$ & $0.23149 \pm 0,05876$ & $26.5847 \pm 7,6633$ & - \\
\hline Bbkf & $0.26046 \pm 0,07163$ & $28.178 \pm 8,3571$ & $38.75 \pm 2,99$ \\
\hline Bbk & $0.2528 \pm 0,00541$ & $3.495 \pm 0,6594$ & $1.84 \pm 0,77$ \\
\hline Bbh & $0.38600 \pm 0,10770$ & $2.9931 \pm 0,6816$ & - \\
\hline
\end{tabular}

Note:

Bbhf $=$ fine coal + mixture of cattle feces and water

Bbkf = coarse coal + mixture of cattle feces and water

Bbk = coarse coal + water

$\mathrm{Bbh}=$ fine coal + water

Tabel 4. Average $\mathrm{N}_{2} \mathrm{O}$ Production in Different Digesters (\% Mol)

\begin{tabular}{lrrr}
\hline \multirow{2}{*}{ Treatment } & \multicolumn{2}{c}{ Hungate Tubes } & Digester 600 ml Digester 30 litre \\
& \multicolumn{2}{c}{----------- \%Mol------------- } \\
\hline Bbhf & $0.9499 \pm 0,02118$ & $26.0906 \pm 22,37$ & - \\
Bbkf & $0.10004 \pm 0,00369$ & $25.2413 \pm 17,33$ & $14.02 \pm 9,58$ \\
Bb+water & $0.09689 \pm 0,04865$ & $96.3597 \pm 0,71$ & $97.73 \pm 0,86$ \\
Bb+water & $0.06966 \pm 0,023155$ & $95.167 \pm 1,92$ & -
\end{tabular}

Note:

Bbhf $=$ fine coal + mixture of cattle feces and water

Bbkf $=$ coarse coal + mixture of cattle feces and water

Bbk = coarse coal + water

$\mathrm{Bbh}=$ fine coal + water

The averages methane production in various digesters observed in this study are shown in Table 5 . Treatment of mixture of fine coal and cow feces (Bbkf) showed methane production in all digester. It means methanogenic bacteria grew in coal media and produce methane.

\section{DISCUSSION}

Methane is mostly formed by acetic acid accounted for $70 \%$, while the remaining is formed by hydrogen and carbon dioxide. Table 1 shows higher production 
Tabel 5. Average $\mathrm{CH}_{4}$ Production (\% Mol)

\begin{tabular}{|c|c|c|c|}
\hline \multirow[t]{2}{*}{ Treatments } & Hungate Tubes & Digester $600 \mathrm{ml}$ & $\begin{array}{c}\text { Digester } 30 \\
\text { litre }\end{array}$ \\
\hline & \multicolumn{3}{|c|}{ 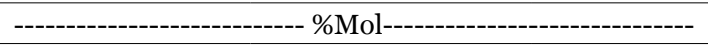 } \\
\hline Bbhf & $0.0210 \pm 0,01935$ & $47.2971 \pm 14,6953$ & \\
\hline Bbkf & $0.0284 \pm 0,01107$ & $45 \cdot 9896 \pm 8,5612$ & $43.64 \pm 10,01$ \\
\hline Bbk & $0.0263 \pm 0,0085$ & $1.1323 \pm 0,7580$ & 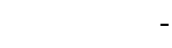 \\
\hline Bbh & -5 & $0.1452 \pm 0,0482$ & \\
\hline \multicolumn{4}{|c|}{$\begin{array}{l}\text { Note: } \\
\text { Bbhf }=\text { fine coal }+ \text { mixture of cattle feces and water } \\
\text { Bbkf }=\text { coarse coal }+ \text { mixture of cattle feces and water } \\
\text { Bbk }=\text { coarse coal }+ \text { water } \\
\text { Bbh }=\text { fine coal }+ \text { water }\end{array}$} \\
\hline
\end{tabular}

of acetic acid than other volatile fatty acids which suggested the potential for methane formation.This stage has been considered as a significant factor that determines the speed of biogas production (Simamora, 1989). The bacteria that play a role in the acidogenes stage are acidogenic bacteria, such as Symtrophomanas wolfei. These acidogenic bacteria produce acetic acid, propionic acid, butyric acid, hydrogen, carbon dioxide and small amount of formic acid, lactic acid, valeric acid, methanol, ethanol, butanediol, and acetone. Organic acids that are critical to methane production in methanogenesis is volatile fatty acids (VFA), which has been utilized to observe the performance of anaerobic digestion process (Dong-Jin et al, 2015; Liet al, 2011; Raposo et al, 2009).

Hydrogen is needed by bacteria in the decomposition of organic matters during acidogenesis stage. Bacteria produce acids which modify $\mathrm{H}_{2}$ and $\mathrm{CO}_{2}$ into simple organic acids for methanogenesis (Wilkie, 2005). Methanogenic bacteria utilize $\mathrm{H}_{2}$ produced by Protozoa and convert it into $\mathrm{CH}_{4}$ (Kurihara, et al. 1978). $\mathrm{No} \mathrm{O}_{2}$ was detected in all treatments, indicating that anaerobic fermentation process occurred.

Carbon dioxide $\left(\mathrm{CO}_{2}\right)$ is the second largest gas from biogas. It is generated from bacterial activity in anaerobic process of organic matter decomposition (Ferry, 2015). In this research, carbon dioxide was needed by methanogens to support their growth, because in metanogenesis phase, carbon dioxide became important in the production of methane when other components in biogas formation depleted. Carbon, nitrogen, phosphorus, and sulphur are macronutrients that support the growth of microorganisms in the methane formation. $\mathrm{CO} 2$ produced from decarboxylation of acetate will react with $\mathrm{H}_{2}$ and produce methane $\left(\mathrm{CH}_{4}\right)$ and carbon dioxide $\left(\mathrm{CO}_{2}\right)$ as the final products (Szuhaj, 2006).

In coal-water mixture $(\mathrm{Bb}), \mathrm{N}_{2}$ dominated biogas composition, indicating that the stage occurred in this mix was still the hydrolysis stage. Decomposition of nitrates, nitrites or denitrification normally occurred in this hydrolysis stage. In this study, the outcome nitrogen did not meet the standards of biogas composition. This indicated that all stages were not completed. If nitrogen content is high, it would be consumed very quickly by methanogenic bacteria to meet their protein requirements, so that it will no longer react with residue of organic carbon. This resulted in inhibition of methane production and led to reduced methane levels.

In methanogenesis stage, methanogenic bacteria slowly form methane in anaerobic conditions. The biogas formation lasts for 14 days at a temperature of $25^{\circ} \mathrm{C}$ in digester (Wiratmanaet al., 2012). Several bacterial genera involved in methanogenesis stage include Methanobacterium, Methanothermobacter, Methanobrevibacter, Methanisarcina, and Methanosaeta (Moris, 2011). Theses bacteria produce methane in two ways, namely by transforming acetic acid (about 70\%) and about 30\% by reducing carbon (Seadiet al., 2008).

Methane production in digester $600 \mathrm{ml}$ was higher than that in drums. This condition is associated with stirring system where the drum was not equipped with a stirrer, while the Hungate tube and $600 \mathrm{ml}$ digester could easily be stirred manually. In large digesters, stirring become very important.The purpose of stirring is to avoid the solid material from sedimenting on the base of the digesters. Mixing prevents sedimentation of particles, creates homogenous mixtures of substrates, and ensures all materials undergo anaerobic fermentation evenly. In addition, stirring can facilitate the release of gas produced by bacteria into the biogas reservoir. As suggested by Carlos Rica et al (2011), stirring systems are still one of the most critical biogas plant components due to floating or sedimenting substances.

\section{CONCLUSION}

Based on the results of this study, it can be concluded that anaerobic bacteria derived from feces of cattle can be grown in coal and have potential to produce coal-bed methane (CBM).

\section{ACKNOWLEDGEMENT}

The authors would like to acknowledge the Academic Leadership Grand (ALG) of Padjadjaran University for its financial support of this research.

\section{REFERENCES}

Beyond Petroleum. 2006. Statistic Data of Energy SourceCountries Of Indonesia. Availableat : http://www. eia.gov

Carlos Rico, Jose Luis Rico, Noella Munoz, BeatriZ Gomez, Inaki Tejero. 2011. Effect of mixing on biogas production during mesophilic anaerobic digestion of screened dairy manure in a pilot plant.DOI: 10.1002/ elsc.201100010.Eng.Life Sci.11(5):476-481.

Dong-Jin Lee, Su-Young Lee, Ji-Su Bae, Jung-Gu Kang, Ki-Heon Kim, Sung-Su Rhee, Jong-Hwan Park, JuSik Cho, Jin Chung and Dong-CheolSeo. 2015. Effect of Volatile Fatty Acid Concentration on Anaerobic Digestion Facilities Treating Food Waste Leachate in South Korea. J. of Chemistry. Available at: https:// 
www.hindawi.com/journals/jchem/2015/640717/

Ferry, J.G. 2015. Review Acetate Metabolism in Anaerobes from the Domain Archaea. life ISSN 2075-1729 www. mdpi.com/journal/life 5, 1454-1471; doi:10.3390/ life5021454

Hammond J.P., M.R. Brodley and P.J. White. 2004. Genetic Responses to Phosphorus Deficiency. Ann. Bot.J. 94:323-332.

Karimi, K. 2005. Coal Bed Methane Reservoir Simulation Studies. M. Sc Thesis, School of Petroleum Engineering-University of New South Wales, Australia, pp. 1-149.

Kurihara, Y.,T. Takechi and F Shibata. 1978. Relationship Between Bacteria and CilliateProtozoa in The Rumen of Sheep Fed on Purified Diet. J.Agric.Scie 90.

Li, Y., S.Y. Park, and J. Zhu. 2011. Solid-State Anaerobic Digestion for Methane Production from Organic Waste. Renewable and Sustainable Energy Reviews 15(1): 821-826.

Merkel, J.A. 1981.Managing Livestock Wastes. AVI Publishing Company. Inc. Westport. Connecticut.

Morris, Rachel. 2011.Relating Methanogen Community Structure to Function in Anaerobic Wastewater Digesters. Dissertation. Marquete University. Milwaukee, Wisconsin

Raposo, F., R. Borja, M. A. Martin, A. Martin, M.A. de la Rubia and B. Rincón. 2009. Influence of InoculumSubstrate Ration on the Anaerobic Digestion of Sunflower Oil Cake in Batch Mode: Process Stability and Kinetic Evaluation. Chemical Engineering J. 149(1-3):70-77.
Saghafi, A. 2001. Coal Seam Gas Reservoir Characterization. Proceeding, Gas from Coal Symposium, Brisbane-Australia.

Seadi , T Rutz, D and Prassl, H.,2008. Biogas Handbook. University of Southern DenmarkEsbjerg, Denmark.

Simamora, 1989. Pengelolaan Limbah Peternakan (Animal Waste Management) Teknologi Energi Gasbio. Fakultas Politeknik Pertanian IPB. Bekerjasama dengan Direktorat Pendidikan Menengah Kejuruan. Dirjen Pendidikan Dasar dan Menengah.Departemen P dan K.

Szuhaj, M, N.Á.R. Tengölics, A. Bodor, G.Rákhely, K.L.Kovács and Zoltán, 2016. Conversion of $\mathrm{H}_{2}$ and $\mathrm{CO}_{2}$ to $\mathrm{CH}_{4}$ and acetate in fed-batch biogas reactors by mixed biogas community: a novel route for the power to-gas conceptBiotechnol Biofuels 9:102 DOI 10.1186/s13068-016-0515-0.

Tim Kajian Batubara Nasional. 2006. Batubara Indonesia. Kelompok Kajian Kebijakan Mineral dan Batubara Pusat Litbang Teknologi Mineral dan Batubara.

Wilkie, A.C. 2005. Anaerobic Digestion: Biology and Benefits.In:Dairy Manure Management: Treatment, Handling, and Community Relations. NRAES-176, p.63-72. Natural Resource, Agriculture, and Engineering Service, Cornell University, Ithaca, NY.

Wiratmana, I.P.A., I Gusti K.S. dan I Gusti Ngurah P.T. 2012. Studi Eksperimental Pengaruh Variasi Bahan Kering Terhadap Produksi dan Nilai Kalor Biogas Kotoran Sapi. Jurnal Energi dan Manufaktur 5(1). 